\title{
Interrelationship between silicon, aluminum, and elements associated with tissue metabolism and degenerative processes in degenerated human intervertebral disc tissue
}

\author{
Anetta Ziola-Frankowska ${ }^{1}$ - Lukasz Kubaszewski ${ }^{2}$ - Mikołaj Dąbrowski ${ }^{2}$. \\ Marcin Frankowski ${ }^{3}$ (D)
}

Received: 25 November 2016 / Accepted: 20 June 2017 /Published online: 7 July 2017

(C) The Author(s) 2017. This article is an open access publication

\begin{abstract}
There is a growing body of evidence concerning the significant role of silicon in development and composition of both connective and bone tissue. Bio-essential silicon shows strong chemical and biological affinity to aluminum, which is toxic and biologically inessential element. The presence of silicon was confirmed in a variety of tissues; however, it has never been examined in intervertebral disc tissue, neither in healthy nor in degenerated one. In this paper, for the first time in the literature, we present the content of silicon in the degenerated intervertebral disc tissue. We also compared the results of silicon analysis with aluminum values in degenerated intervertebral disc tissue in humans. We used chemometric methods to find correlations and similarities between silicon, aluminum, and elements associated with tissue metabolism $(\mathrm{Mg})$ and degenerative processes $(\mathrm{Zn}$ and $\mathrm{Cu}$ ). The presence of silicon was confirmed in all 30 samples harvested from 22 patients operated on due to degenerative changes. Its concentration was within the range of 5.37$12.8 \mu \mathrm{g} \mathrm{g}^{-1} \mathrm{~d}$.w., with the mean concentration of
\end{abstract}

Responsible editor: Philippe Garrigues

Anetta Zioła-Frankowska

anettazf@amu.edu.pl

$\triangle$ Marcin Frankowski

marcin.frankowski@amu.edu.pl

1 Department of Analytical Chemistry, Faculty of Chemistry, Adam Mickiewicz University in Poznań, Umultowska 89b, 61-614 Poznan, Poland

2 Department of Spondyloortopaedics and Biomechanics of the Spine, W. Dega University Hospital, Poznan University of Medical Sciences, 28 Czerwca 1956 135/147, 61-545 Poznan, Poland

3 Department of Water and Soil Analysis, Faculty of Chemistry, Adam Mickiewicz University in Poznań, Umultowska 89b,

61-614 Poznan, Poland
$7.82 \mu \mathrm{g} \mathrm{g}^{-1}$ d.w. The analysis showed significant correlation between $\mathrm{Si}$ and both $\mathrm{Al}$ and $\mathrm{Mg}$ and weak or negative correlation with $\mathrm{Zn}$ and $\mathrm{Cu}$, where the latter was probably the result of degenerative processes. Although silicon is considered essential in glycosaminoglycan and collagen synthesis in connective tissue, it did not show any correlation nor similarities with elements reflecting changes associated with the degenerative process of the intervertebral disc. Silicon showed significant correlation with aluminum, similar to those observed in other human tissues.

Keywords Silicon · Aluminum · Intervertebral disc tissue . Spine $\cdot$ Si-Al correlation

\section{Introduction}

Until the 1970s, silicon was considered as a biologically insignificant element. Even now, some authors tend to recognize silicon as a non-essential microelement. The first studies that hypothesized its significance in bone formation and glycosaminoglycan composition were published in the 1970s (Carlise 1970). Further analyses confirmed its important role in bone and connective tissue, and its influence on mechanical properties and endurance of the tissues (Nielsen and Sandstead 1974; Carlisle 1981; Lugowski et al. 1998; Jugdaohsingh 2007; Kim et al. 2014). Based on the abundance in the human body, we may distinguish three groups of chemical elements, depending on their concentration in tissues: (1) major dietary elements such as calcium, phosphorus, potassium, sulfur, sodium, chlorine, and magnesium; (2) minor dietary or trace elements such as iron, cobalt, copper, zinc, manganese, molybdenum, iodine, bromine, and selenium; and (3) others, considered as "ultratrace" elements (due to very low concentration and not clear role)-boron and chromium. The 
elements such as arsenic and silicon, due to lack of sufficient studies, cannot be attributed to any of the groups. Other classification divides elements into three major groups with respect to their biological role: essential, potentially essential, or not essential for the organism (Kabata-Pendias and Mukherjee 2007). The essentiality of elements is to some degree connected with their tissue concentration in dry mass, reflecting the number of biochemical processes in which they take part. The metabolically significant elements are usually within concentration ranges expressed in $\mathrm{mg} / \mathrm{kg}$, e.g., magnesium, zinc, or copper (Nowakowski et al. 2015; Kubaszewski et al. 2014). Potentially significant elements are within one order of magnitude lower concentration ranges, i.e., $\mu \mathrm{g} \mathrm{kg}^{-1}$ d.w. Ni, Co, Mo with the available analytical techniques they may not be detected in every sample (Kubaszewski et al. 2014). The silicon is considered to be a transition element. In the periodic table, it is placed between nonmetals and metals. The proximity of silicon to carbon, some similarities to this organic compounds backbone, as well as the abundance in the environment, may indirectly suggest silicon significance in biochemistry. Indeed, skeletons of primitive animals, bacteria, and plants (diatoms, radiolaria, siliceous sponges) are built of silicon (Exley 2009a). Its role in humans is ultimately not defined (Martin 2013). The studies show that it plays a crucial role in collagen-rich tissues integrity (nail, skin, hair), collagen synthesis, bone tissue development and regeneration, as well as in the reduction of aluminum accumulation, which reflects the risk of Alzheimer's disease (Schwarz and Milne 1972; Exley et al. 2006; Rodella et al. 2014; Jugdaohsingh et al. 2015). Silicon is a substantial element of collagen and glycosaminoglycan-rich tissues (Reffitt et al. 2003; Spector et al. 2005; Pruksa et al. 2014). One of such tissues is the intervertebral disc (IVD). In IVD, both collagen dysfunction and glycosaminoglycan decomposition are considered a direct cause of the degeneration process, with loss of the biomechanical function - clinically symptomatic back pain, resulting in substantial costs to the health care system (Nowakowski et al. 2015). To our knowledge, there have been no analyses or published papers on silicon concentration in degenerated IVD. Also, silicon in the form of silicic acid is regarded as a natural antagonist of aluminum toxicity in biota and in humans. It reduces aluminum uptake across the gut and simplifies the excretion of systemic aluminum via kidneys (Exley 2009a; Davenward et al. 2013). Moreover, the studies presented an evidence that long-term drinking of silicon-rich mineral water significantly reduces the body burden of $\mathrm{Al}$ (Exley et al. 2006; Davenward et al. 2013). Silicon is also important for the immune system and prevents arteriosclerosis. However, officially, it is still not considered as an essential nutrient for humans (Martin 2013).

In spite of the abovementioned facts, our knowledge on silicon concentration and distribution in human tissues is not even satisfactory. It is considered as the third most abundant microelement (1-10 $\left.\mathrm{mg} \mathrm{kg}^{-1}\right)$ in humans. However, this assumption is based on data derived from "insignificant" tissues such as the hair, nails, and epidermis. In the literature, we can also find some results of silicon analysis in the serum and urine, which are discussed in terms of Si intake, accumulation, and excretion characteristics (Jugdaohsingh 2007). To our knowledge, so far, human mechanical tissues have not been analyzed for $\mathrm{Si}$ concentration and $\mathrm{Si}-\mathrm{Al}$ relations.

The aim of this research was to determine the concentration of $\mathrm{Si}$ in degenerated IVD in humans, by ICP-OES analytical technique, and check the correlations between $\mathrm{Si}$ and $\mathrm{Al}, \mathrm{Cu}$, $\mathrm{Zn}$, and $\mathrm{Mg}$, found in the analyzed tissues, by statistical methods.

\section{Materials and methods}

A total of 30 samples of degenerated IVD were harvested from 22 patients undergoing surgical discectomy or spinal fusion due to degenerative disc disease. The samples were obtained from the cervical spine ( 12 samples from 6 patients) and from the lumbar spine (18 samples from 16 patients). The pre-operative magnetic resonance images, taken to evaluate degeneration status of the operated disc, were scored according to the Pfirrmann classification (Pfirmann et al. 2001). The use of tissues for this study was approved by the appropriate bioethics committee, and the written consent was obtained from all patients. The permission was given by the Bioethics Committee of Institute of Rheumatology, Warsaw, on May 31, 2012, and Bioethics Committee of University of Medical Sciences, Poznan, (No.406/13). The average age of patients at the time of operation was 47.6 (range 28-64 years). The information on demography, health status, and occupational exposure to heavy metals was collected from all patients. The patients involved in the study were not exposed to heavy metal pollution.

The degenerated IVD samples were frozen. Prior to the analysis, they were freeze-dried using a Lyovac lyophilizer GT2e (Steris, Germany), for $24 \mathrm{~h}$. The samples were weighed after drying and placed in Teflon vessels. The supra-pure nitric acid (V) (Merck, Germany) was added to obtain a maximum dilution factor of 10 . The amounts of dry samples ranged from 0.2 to $0.6 \mathrm{~g}$, and the amounts of acid were from 2.0 to $6.0 \mathrm{ml}$. Then, samples with acid were left to stand overnight to slow mineralization. After this step, samples were mineralized in a microwave oven (Mars Xpress 5, CEM USA), based on the modified 3051 EPA method (Zioła-Frankowska et al. 2015, 2016). In the case of $\mathrm{Si}, 200 \mu \mathrm{L}$ of $1 \%$ supra-pure hydrofluoric acid (Merck, Germany) was added to the extracts of IVD tissues to prevent the precipitation of silicon in an acid medium. The concentration of $\mathrm{Si}$ was determined using a Shimadzu ICPE 9820 ICP-OES spectrometer (Shimadzu, 
Table 1 Operating conditions and accessories employed in ICPOES spectrometer (Shimadzu ICPE-9820) for analysis of intervertebral discs samples

\begin{tabular}{|c|c|c|}
\hline \multicolumn{2}{|c|}{ Parameter and accessories } & Value \\
\hline \multicolumn{2}{|c|}{ Radio frequency power generator } & $1.2 \mathrm{~kW}$ \\
\hline \multicolumn{2}{|l|}{ Gas type } & Argon \\
\hline \multicolumn{2}{|c|}{ Plasma gas flow rate } & $10.0 \mathrm{~L} \mathrm{~min}^{-1}$ \\
\hline \multicolumn{2}{|c|}{ Auxiliary gas flow rate } & $0.6 \mathrm{~L} \mathrm{~min}-1$ \\
\hline \multicolumn{2}{|c|}{ Nebulization gas flow rate } & $0.7 \mathrm{~L} \mathrm{~min}^{-1}$ \\
\hline \multicolumn{2}{|l|}{ Plasma view } & Vertical torch; axial view \\
\hline \multirow{2}{*}{\multicolumn{2}{|c|}{ Selected emission lines (atomic) }} & $251.611(\mathrm{BEC}=0.084)$ \\
\hline & & $212.412(\mathrm{BEC}=0.188)$ \\
\hline \multicolumn{2}{|l|}{ Torch } & Mini-torch (quartz) \\
\hline \multicolumn{2}{|l|}{ Nebulizer } & Burgener NX-175 \\
\hline \multicolumn{2}{|l|}{ Chamber } & Cyclone (glass) \\
\hline \multicolumn{2}{|l|}{ Drain } & Gravity fed \\
\hline \multicolumn{2}{|l|}{ Injector tube } & Quartz (1.2 mm i.d.) \\
\hline \multicolumn{2}{|c|}{ Background correction } & 2-points \\
\hline \multicolumn{2}{|c|}{ Number of replicates } & 3 \\
\hline \multicolumn{2}{|l|}{ Exposure time } & $15 \mathrm{~s}$ \\
\hline \multirow[t]{3}{*}{ Peristaltic pump } & Solvent rinse & $15 \mathrm{~s}$ \\
\hline & Sample rinse & $15 \mathrm{~s}$ \\
\hline & Sample uptake rate & $1 \mathrm{ml} \mathrm{min}{ }^{-1}$ \\
\hline \multirow[t]{3}{*}{ Spectrometer } & Echelle optics & Range of wavelength: 167 to $800 \mathrm{~nm}$ \\
\hline & Resolution & $\leq 0.005 \mathrm{~nm}$ at $200 \mathrm{~nm}$ \\
\hline & Atmospheric removal system & Rotary vacuum pump $\leq 10 \mathrm{~Pa}$ \\
\hline \multirow[t]{4}{*}{ Device } & CCD (charge coupled device) detector & \\
\hline & Pixel number & $1024 \times 1024$ pixels $(1$ in. $)$ \\
\hline & Pixel size & $20 \mu \mathrm{m} \times 20 \mu \mathrm{m}$ \\
\hline & Cooling control & Peltier device \\
\hline
\end{tabular}

Japan). The optimized operating conditions for the analysis of $\mathrm{Si}$ in IVD samples are presented in a table (Table 1).

The concentration of $\mathrm{Al}$ and $\mathrm{Cu}$ was determined by a Shimadzu AAS 7000 spectrometer (Shimadzu, Japan) with graphite furnace atomization (GF-AAS). The concentration of $\mathrm{Mg}$ and $\mathrm{Zn}$ was determined with the use of the Shimadzu AAS 7000 with flame atomization (F-AAS). The optimized parameters for determination of metals have been presented in the study (Kubaszewski et al. 2014). The concentrations of the other metals, obtained by Kubaszewski et al. (2014) are presented in Table 2.

Table 2 Concentration of $\mathrm{Al}, \mathrm{Cu}, \mathrm{Mg}$, and $\mathrm{Zn}$ in intervertebral disc (Kubaszewski et al. 2014)

\begin{tabular}{|c|c|c|c|}
\hline Element & $\begin{array}{l}\mathrm{AM} \\
{\left[\mu \mathrm{g} \mathrm{g}^{-1} \text { d.w. }\right]}\end{array}$ & S.D. & Range \\
\hline $\mathrm{Al}$ & 0.664 & 0.289 & $0.166-1.271$ \\
\hline $\mathrm{Cu}$ & 3.41 & 4.045 & $0.97-23.64$ \\
\hline $\mathrm{Mg}$ & 800.1 & 525.5 & $182.6-2132$ \\
\hline $\mathrm{Zn}$ & 39.60 & 35.95 & $10.56-184.5$ \\
\hline
\end{tabular}

$A M$ arithmetic mean, S.D. standard deviation
To estimate the correlation of silicon and the selected metals, the statistical analysis was performed with Statistica v. 7.0 (StatSoft, Poland). In the standardization process, all values of selected variables were replaced by standardized values, which were computed as follows: Std. score $=$ (raw score - mean)/Std. deviation. The Spearman rank-order correlation analysis was performed to determine correlation between $\mathrm{Si}$ and the other elements ( $\mathrm{Al}, \mathrm{Cu}, \mathrm{Mg}$, and $\mathrm{Zn}$ ) and epidemiological data (age, sex, degeneration based on Pfirrmann score, area of degeneration: cervical or lumbar spine). Moreover, chemometric analysis of the analyzed

Table 3 Spearman's rank correlation order of the elements measured in intervertebral disc samples

\begin{tabular}{llllll}
\hline Spearman & $\mathrm{Al}$ & $\mathrm{Si}$ & $\mathrm{Cu}$ & $\mathrm{Mg}$ & $\mathrm{Zn}$ \\
\hline $\mathrm{Al}$ & $\mathrm{x}$ & & & & \\
$\mathrm{Si}$ & $0.47^{*}$ & $\mathrm{x}$ & & & \\
$\mathrm{Cu}$ & -0.25 & $-0.50^{*}$ & $\mathrm{x}$ & & \\
$\mathrm{Mg}$ & $0.50^{*}$ & $0.46^{*}$ & -0.32 & $\mathrm{x}$ & \\
$\mathrm{Zn}$ & 0.27 & 0.09 & -0.08 & $0.75^{*}$ & $\mathrm{x}$ \\
\hline
\end{tabular}

*Statistically significant; $p$ value $<0.01$ 
Table 4 Silicon concentration in intervertebral disc (in $\mu \mathrm{g} \mathrm{g}^{-1}$ d.w.) according to the selected factors

\begin{tabular}{|c|c|c|c|c|c|}
\hline Factors & & $N$ & $\mathrm{AM} \pm$ S.D. $\left[\mu \mathrm{g} \mathrm{g}^{-1}\right]$ & Med. (QL-QU) $\left[\mu \mathrm{g} \mathrm{g}^{-1}\right]$ & Mann-Whitney $U$ test \\
\hline Gender & $\begin{array}{l}\text { Men } \\
\text { Women }\end{array}$ & $\begin{array}{l}18 \\
12\end{array}$ & $\begin{array}{l}8.3 \pm 1.6 \\
7.1 \pm 1.8\end{array}$ & $\begin{array}{l}8.3(7.2-8.6) \\
6.5(5.6-8.3)\end{array}$ & 0.046 \\
\hline Implants & $\begin{array}{l}\text { No } \\
\text { Yes }\end{array}$ & $\begin{array}{l}21 \\
9\end{array}$ & $\begin{array}{l}8 \pm 1.9 \\
7.4 \pm 1.5\end{array}$ & $\begin{array}{l}8.3(6.6-8.8) \\
7.4(6.5-8.3)\end{array}$ & 0.46 \\
\hline Intervertebral disc from & $\begin{array}{l}\text { Lumbar } \\
\text { Cervical }\end{array}$ & $\begin{array}{l}18 \\
12\end{array}$ & $\begin{array}{l}8.5 \pm 1.8 \\
6.8 \pm 1.2\end{array}$ & $\begin{array}{l}8.4(7.2-9.7) \\
6.5(5.7-8.1)\end{array}$ & 0.016 \\
\hline
\end{tabular}

$N$ number of samples, $M e d$. median, $Q L$ lower quartile, $Q U$ upper quartile

elements was performed. After autoscaling, the similarity analysis was performed with graphical methods. Tangent distances $\left(d^{\mathrm{T}}\right)$ were calculated and relationships between the elements were analyzed using a dendrogram.

\section{Results}

The results of such research could reveal the role of silicon in IVD, as well as promote new studies on the pathogenesis and the possible treatment. In this study, we present the concentration of silicon in degenerated human IVD. Furthermore, we try to find relationships between $\mathrm{Si}$ and metabolically related elements such as $\mathrm{Mg}, \mathrm{Zn}$, and $\mathrm{Cu}$. As silicon presents both ex vivo and in vivo high affinity to toxic aluminum, we also included this element in the study. The measured concentrations of silicon were from 5.37 to12.8, with the mean of 7.82 and SD of 1.76 (all in $\mu \mathrm{g} \mathrm{g}^{-1}$ d.w.). Moreover, we analyzed the results according to the age and gender of patients included in the study. In the group of women, the lowest obtained concentration of $\mathrm{Si}$ amounted to $5.37 \mu \mathrm{g} \mathrm{g}^{-1}$ d.w. (42 years old female), and the highest was $10.7 \mu \mathrm{g} \mathrm{g}^{-1}$ d.w. (28 years old female). In men, the lowest determined concentration of $\mathrm{Si}$ amounted to $5.72 \mu \mathrm{g} \mathrm{g}^{-1}$ d.w. (38 years old male), and the highest was $12.8 \mu \mathrm{g} \mathrm{g}^{-1}$ d.w. (61 years old male). We observed that in females, the highest concentration of $\mathrm{Si}$ occurred in a patient under 40 years old, and in males - in a patient who was over 40 years old.

Based on the results of the statistical analysis, it was observed that $\mathrm{Si}$ showed significant positive correlation with both $\mathrm{Mg}$ and $\mathrm{Al}$, no correlation was found for $\mathrm{Si}$ and $\mathrm{Zn}$, and a significant negative correlation was found for $\mathrm{Si}$ and $\mathrm{Cu}$. Also, there was no correlation between $\mathrm{Si}$ and age, sex, and degeneration score based on the Pfirrmann classification (Pfirrmann et al. 2001). The correlations between the analyzed elements in the intervertebral disc were described by the Spearman rank correlation (Table 3).

Statistically significant higher content of $\mathrm{Si}$ was observed in men. The cervical disc in comparison to lumbar disc was characterized by statistically significant lower $\mathrm{Si}$ content. There was no statistical difference in Si content between patients who had undergone a surgery with implants and those who had not had such surgery. The results of statistical analysis are presented in Table 4.

Based on the results of the Spearman correlation (Table 5), it was found that $\mathrm{Si}$ concentration significantly increased with concentrations of $\mathrm{Al}$ and $\mathrm{Mg}$ and decreased with $\mathrm{Cu}$ concentration. We observed gender differences in the correlation between $\mathrm{Si}$ and $\mathrm{Mg}$ - a statistically significant increase in $\mathrm{Si}$ concentration in the intervertebral disc with the increase in $\mathrm{Mg}$ concentration was noticed only in female patients. Statistically significant positive correlations between $\mathrm{Si}$ and

Table 5 Spearman rank correlation between $\mathrm{Si}$, the other analyzed metals, and clinical factors (gender, implants, type of spine, patient's age, and Pfirrmann et al. (2001) score)

\begin{tabular}{|c|c|c|c|c|c|c|c|}
\hline \multirow[b]{2}{*}{$\mathrm{Si}$} & & \multicolumn{2}{|l|}{ Sex } & \multicolumn{2}{|c|}{ Implants } & \multicolumn{2}{|c|}{ Intervertebral disc from } \\
\hline & & Men & Women & No & Yes & Lumbar & Cervical \\
\hline $\mathrm{Al}$ & $0.47 *$ & 0.35 & 0.48 & $0.53 *$ & $0.77 *$ & $0.59 *$ & 0.48 \\
\hline $\mathrm{Cu}$ & $-0.40^{*}$ & 0.02 & -0.29 & -0.35 & $-0.70 *$ & -0.24 & $-0.83^{*}$ \\
\hline $\mathrm{Mg}$ & $0.56^{*}$ & 0.21 & $0.68^{*}$ & $0.65^{*}$ & 0.60 & $0.52 *$ & $0.76^{*}$ \\
\hline $\mathrm{Zn}$ & 0.20 & -0.05 & 0.25 & 0.15 & $0.67 *$ & 0.16 & $0.62 *$ \\
\hline age & -0.03 & 0.26 & -0.27 & -0.22 & $0.79 *$ & 0.00 & 0.12 \\
\hline Pfirrmann & -0.06 & -0.13 & -0.04 & -0.09 & 0.00 & 0.12 & -0.42 \\
\hline
\end{tabular}

* Statistically significant 
Fig. 1 Scatterplot of standardized Si against standardized $\mathrm{Al}$

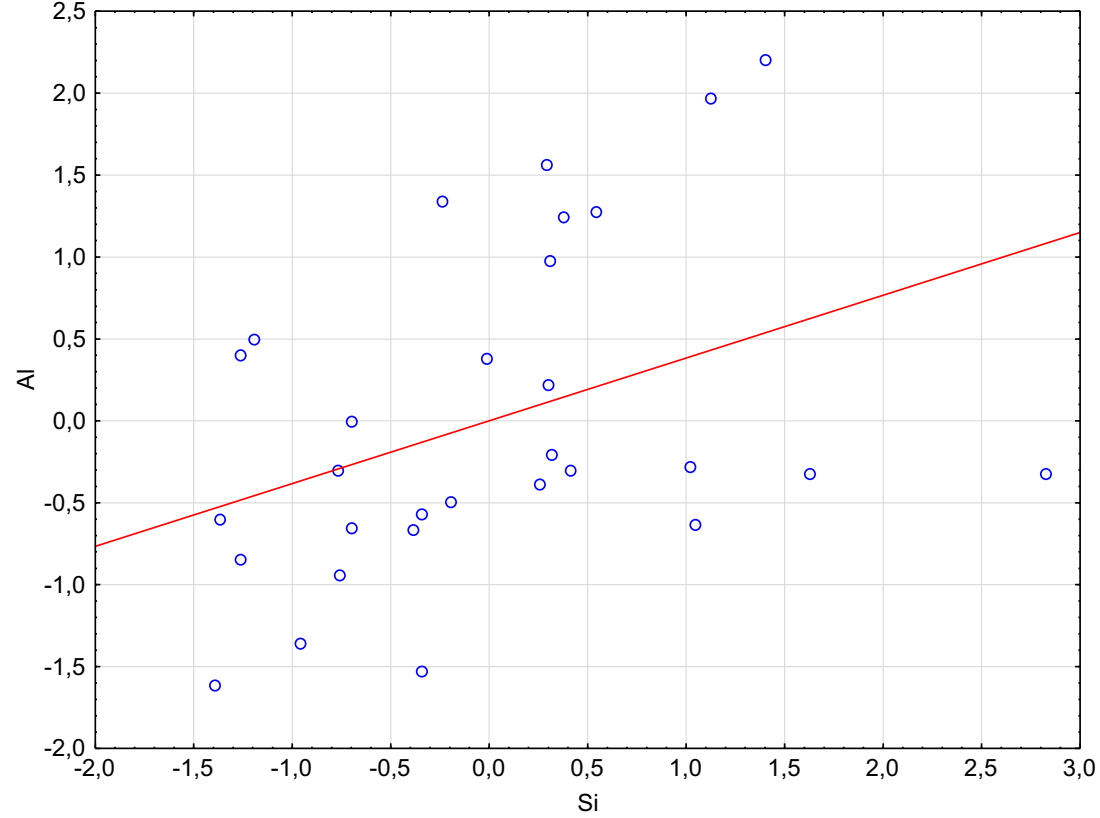

$\mathrm{Pb}, \mathrm{Zn}$, and age were found only in patients who had undergone a surgery with implants.

In order to define correlations between silicon and the other metals determined in intervertebral disc samples, the similarity analysis was performed. The distribution analysis for silicon showed similarities between concentrations of both $\mathrm{Al}$ and $\mathrm{Mg}$ (Figs. 1 and 2), while the distribution patterns between the following elements $\mathrm{Si}-\mathrm{Cu}$ and $\mathrm{Si}-\mathrm{Zn}$ confirmed no similarities between them (Figs. 3 and 4).

Based on tangent distance $\left(d^{\mathrm{T}}\right)$ matrix, the smallest distances graph was performed (Fig. 5) and two main groups were distinguished. The first group included $\mathrm{Mg}, \mathrm{Zn}$, and $\mathrm{Cu}$, while the second group included Si and Al. Although the distance between $\mathrm{Mg}$ and $\mathrm{Al}$ was smaller than that between $\mathrm{Al}$ and $\mathrm{Si}$ (1.64 and 2.41, respectively), the distances between $\mathrm{Al}$ and the other analyzed elements were relatively high. The graph (Fig. 5) presents lack of similarities between $\mathrm{Si}$ and other metabolically related elements, i.e., $\mathrm{Mg}, \mathrm{Zn}$, and $\mathrm{Cu}$.

\section{Discussion}

The majority of studies dealing with silicon in human tissues were performed in patients with breast implants, due to growing popularity of the cosmetic surgery. The research of McConnell et al. (1997) showed that the silicon level in parenchymal tissue of natural (not augmented) breasts was $64 \mu \mathrm{g} \mathrm{g}^{-1}$, whereas Peters et al. (1996) determined much lower concentrations of silicon in 16 breast tissue samples,
Fig. 2 Scatterplot of standardized Si against standardized $\mathrm{Mg}$

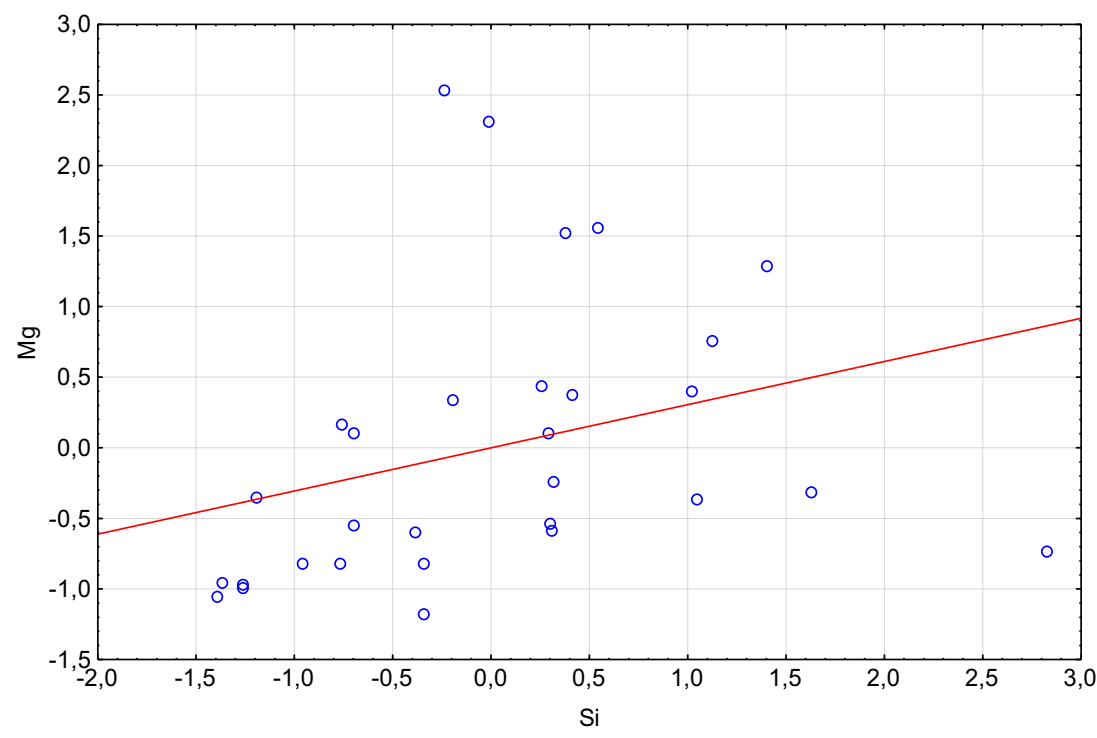


Fig. 3 Scatterplot of standardized Si against standardized $\mathrm{Cu}$

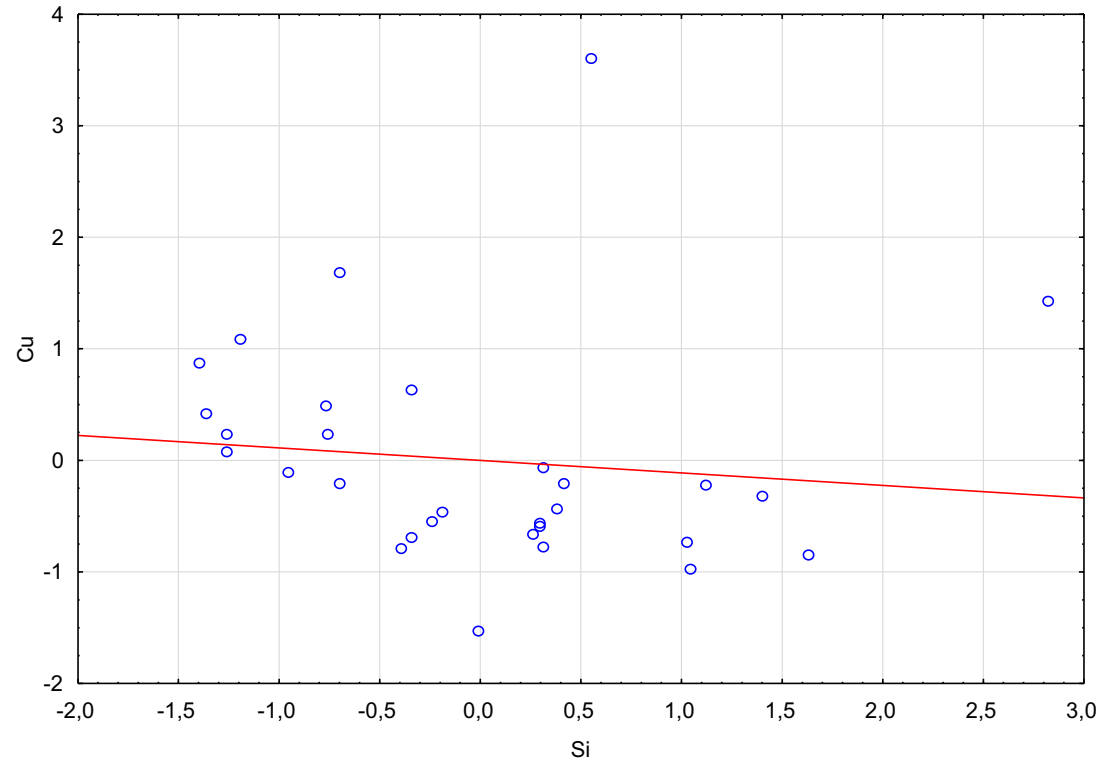

from 0.046 to $0.742 \mu \mathrm{g} \mathrm{g}^{-1}$ of dry weight, with the mean value of $0.0927 \mu \mathrm{g} \mathrm{g}^{-1}$. Other studies showed mean Si concentrations of $12-27 \mu \mathrm{g} \mathrm{g}^{-1}$ for human tissues, including the brain, and gave total body burden values of several grams (D'Haese et al. 1995). In this study, we generally determined much higher concentrations of $\mathrm{Si}$ in human tissues (IVD) than other authors, except for McConnell et al. (1997). The concentrations of $\mathrm{Si}$ measured in degenerated intervertebral disc tissues in humans were within the range of 5.37-12.8 $\mu \mathrm{g} \mathrm{g}^{-1}$. This justifies to consider silicon as an element that is somewhere between the major and minor dietary elements. The potential role of the silicon in the intervertebral disc can be derived from previous studies on animals and humans. It has been confirmed that silicon supplementation can promote new bone formation and regeneration, both in fracture healing and osteoporosis (Jugdaohsingh et al. 2004; Nielsen 2014). The human cohort studies suggested that higher silicon intake is associated with higher bone mineral density (BMD) and with higher bone remodeling marker level (Jugdaohsingh et al. 2004; MacDonald et al. 2012). Silicon deficiency may cause decreased concentrations of $\mathrm{Ca}, \mathrm{Mg}, \mathrm{Cu}, \mathrm{K}$, and $\mathrm{Zn}$ in bones (Seaborn and Nielsen 2002). We confirmed this fact in our distance analysis. Also, silicon can influence the absorption, retention, and behavior of mineral elements $(\mathrm{Al}, \mathrm{Mg}$, and $\mathrm{Cu}$ ) (Nielsen 2014). In this study, we statistically confirmed strong relationship between $\mathrm{Si}$ and $\mathrm{Al}$ and between $\mathrm{Si}$ and $\mathrm{Mg}$ in human spinal tissues. It is worth noticing that our research, for the first time, confirmed the similarity between $\mathrm{Si}$ and $\mathrm{Al}$
Fig. 4 Scatterplot of standardized Si against standardized $\mathrm{Zn}$

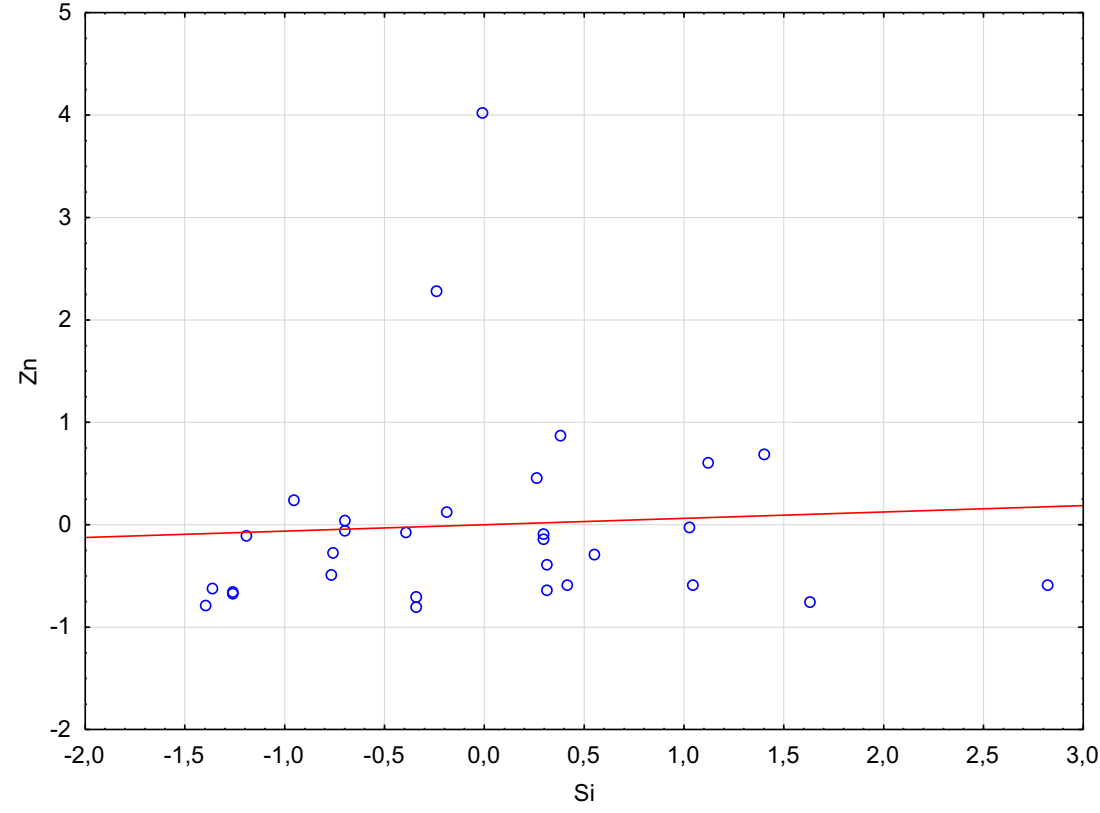


Fig. 5 Smallest-distance graph

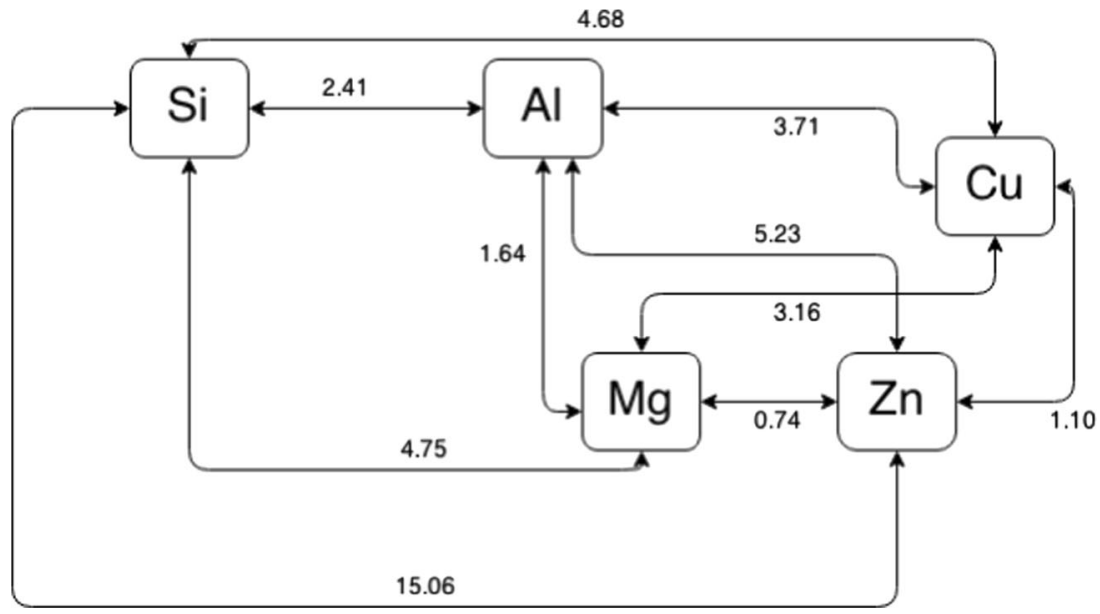

for human intervertebral disc tissue. Our observations are in compliance with those which show a strong relationship of silicon and aluminum, both in humans and in biota (Exley 2009a, b; Davenward et al. 2013). Birchall et al. (1996) suggested that deficiency of silicon and its influence on collagen and osteogenesis may be due to low copper utilization. Based on the results of the present study, the similarities between $\mathrm{Si}$ and $\mathrm{Cu}$ and also between $\mathrm{Si}$ and $\mathrm{Zn}$ cannot be proved. The relationship between Si content and age was not statistically confirmed. However, higher Si concentrations were determined in younger female patients (age range 28-34 years) as compared to older ones (42-64 years). Jugdaohsingh et al. (2013) also found higher Si concentration in the serum of the neonates as compared to the adults. The study of silicon content in the connective tissues from human aorta showed that $\mathrm{Si}$ decreased with age.

\section{Conclusions}

Although many studies have been devoted to the supplementation of humans with silicon and to determining the effect of $\mathrm{Si}$ on the human body, especially on bones, there are no studies that deal with silicon content of human spinal tissues (Davenward et al. 2013; Pruksa et al. 2014; Jugdaohsingh et al. 2013; Li et al. 2010). This can be confirmed by the review of Rodella et al. (2014) which proves beneficial effect of $\mathrm{Si}$ on human bones but contains no information on the studies of Si content in human bone tissues nor in spine tissues. Our study, for the first time, presents the results of silicon analysis in the human intervertebral disc. We confirmed strong correlation between $\mathrm{Si}$ and $\mathrm{Al}$ in the analyzed tissues. Taking into account the general statement that silicon limits the toxicity of aluminum (Birchall et al. 1989; Van Landeghem et al. 1998; Parry et al. 1998; Exley 2009a), our results can be fundamental information which will help to recognize the mechanism of interaction between $\mathrm{Si}$ and $\mathrm{Al}$ in the human body
Open Access This article is distributed under the terms of the Creative Commons Attribution 4.0 International License (http:// creativecommons.org/licenses/by/4.0/), which permits unrestricted use, distribution, and reproduction in any medium, provided you give appropriate credit to the original author(s) and the source, provide a link to the Creative Commons license, and indicate if changes were made.

\section{References}

Birchall JD, Bellia JP, Roberts NB (1996) On the mechanisms underlying the essentiality of silicon -interactions with aluminium and copper. Coord Chem Rev 149:231-240

Birchall JD, Exley C, Chappell JS, Phillips MJ (1989) Acute toxicity of aluminium to fish eliminated in silicon-rich acid waters. Nature 338: 146-148

Carlise EM (1970) Silicon: a possible factor in bone calcification. Science 167(3916):279-280

Carlisle EM (1981) Silicon: a requirement in bone formation independent of vitamin D1. Calcif Tissue Int 33:27-34

Davenward S, Bentham P, Wright J, Crome P, Job D, Polwart A, Exley C (2013) Silicon-rich mineral water as a non-invasive test of the 'aluminum hypothesis' in Alzheimer's disease. J Alzheimers Dis 33:423-430

D'Haese PC, Shaheen FA, Huraid SO, Djukanovic L, Polenakovic MH, Spasovski G, Shikole A, Schurgers ML, Daneels RF, Lamberts LV, Van Landeghem GF, De Broe ME (1995) Increased silicon levels in dialysis patients due to high silicon content in the drinking water, inadequate water treatment procedures, and concentrate contamination: a multicentre study. Nephrol Dial Transplant 10:1838-1844

Exley C, Korchazhkinab O, Jobc D, Strekopytova S, Polwartd A, Cromece P (2006) Non-invasive therapy to reduce the body burden of aluminium in Alzheimer's disease. J Alzheimers Dis 10:17-24

Exley C (2009a) Darwin, natural selection and the biological essentiality of aluminium and silicon. Trends Biochem Sci 34(1):589-593

Exley C (2009b) Silicon in life: whither biological silicification? Prog Mol Subcell Biol 47:173-184

Jugdaohsingh R, Tucker KL, Qiao N, Cupples LA, Kiel DP, Powell JJ (2004) Dietary silicon intake is positively associated with bone mineral density in men and premenopausal women of the Framingham Offspring Cohort. J Bone Miner Res 19:297-307

Jugdaohsingh R (2007) Silicon and bone health. J Nutr Health Aging 11: 99-110

Jugdaohsingh R, Anderson SHC, Lakasing L, Sripanyakorn S, Ratcliffe S, Powell JJ (2013) Serum silicon concentrations in pregnant women and newborn babies. Br J Nutr 110:2004-2010 
Jugdaohsingh R, Watson AIE, Pedro LD, Powell JJ (2015) The decrease in silicon concentration of the connective tissues with age in rats is a marker of connective tissue turnover. Bone 75:40-48

Kabata-Pendias A, Mukherjee AB (2007) Trace elements from soil to human (Book) Trace elements from soil to human 1-550

Kim MH, Kim EJ, Jung JY, Choi MK (2014) Effect of water-soluble silicon supplementation on bone status and balance of calcium and magnesium in male mice. Biol Trace Element Res 158:238-242

Kubaszewski Ł, Zioła-Frankowska A, Frankowski M, Nowakowski A, Czabak-Garbacz R, Kaczmarczyk J, Gasik R (2014) Atomic absorption spectrometry analysis of trace elements in degenerated intervertebral disc tissue. Med Sci Monit 20:2157-2164

Li Z, Karp H, Zerlin A, Carpenter C, Heber D (2010) Absorption of silicon from artesian aquifer water and its impact on bone health in postmenopausal women: a 12 week pilot study. Nutr J 9(44):1-6

Lugowski SJ, Smith DC, Lugowski JZ, Peters W, Semple J (1998) A review of silicon and silicone determination in tissue and body fluids - a need for standard reference materials. Fresenius J Anal Chem 360:486-488

MacDonald HM, Hardcastle AC, Jugdaohsingh R, Fraser WD, Reid DM, Powell JJ (2012) Dietary silicon interacts with oestrogen to influence bone health: evidence from the Aberdeen Prospective Osteoporosis Screening Study. Bone 50:681-687

Martin KR (2013) Chapter 14. Silicon: the health benefits of a metalloid. In: Sigel A, Sigel H, Sigel RKO. Interrelations between essential metal ions and human diseases. Metal Ions in Life Sciences. Springer Science \& Business Media

Mcconnell JP, Moyer TP, Nixon DE, Schnur PL, Salomao DR, Crotty TB, Weinzweig J, Harris JB, Petty PM (1997) Determination of silicon in breast and capsular tissue from patients with breast implants performed by inductively coupled plasma emission spectroscopy: comparison with tissue histology. Am J Clin Pathol 107:236246

Nielsen FH, Sandstead HH (1974) Are nickel, vanadium, silicon, fluorine, and tin essential for man? Am J Clin Nutr 27:515-520

Nielsen FH (2014) Update on the possible nutritional importance of silicon. J Trace Elem Med Biol 28:379-382

Nowakowski A, Kubaszewski Ł, Frankowski M, Wilk-Frańczuk M, Zioła-Frankowska A, Czabak-Garbacz R, Kaczmarczyk J, Gasik R (2015) Analysis of trace element in intervertebral disc by atomic absorption spectrometry techniques in degenerative disc disease in the Polish population. Ann Agric Environ Med 22(2):362-367

Parry R, Plowman D, Delves HT, Roberts NB, Birchall JD, Bellia JP, Davenport A, Ahmad R, Fahal I, Altmann P (1998) Silicon and aluminium interactions in haemodialysis patients. Nephrol Dial Transplant 13(7):1759-1762

Peters W, Smith D, Lugowski S, McHugh A, MacDonald P, Baines C (1996) Silicon and silicone levels in patients with silicone implants. Curr Top Microbiol Immunol 210:31-48

Pfirrmann CW, Metzdorf A, Zanett M et al (2001) Magnetic resonance classification of lumbar intervertebral disc degeneration. Spine 26: 1873-1878

Pruksa S, Siripinyanond A, Powell JJ, Jugdaohsingh R (2014) Silicon balance in human volunteers; a pilot study to establish the variance in silicon excretion versus intake. Nutr Metab 11(1/4):1-8

Reffitt DM, Ogston N, Jugdaohsingh R et al (2003) Orthosilicic acid stimulates collagen type I synthesis and osteoblastic differentiation in human osteoblast-like cells in vitro. Bone 32:127-135

Rodella LF, Bonazza V, Labanca M, Lonati C, Rezzani R (2014) A review of the effects of dietary silicon intake on bone homeostasis and regeneration. J Nutr Health Aging 18(9):820-826

Schwarz K, Milne DB (1972) Growth-promoting effects of silicon in rats. Nature 239:333-334

Seaborn CD, Nielsen FH (2002) Dietary silicon and arginine affect mineral element composition of rat femur and vertebra. Biol Trace Elem Res 89(3):239-250

Spector TD, Calomme MR, Anderson S, Swaminathan R, Jugdaohsingh R, Vanden-Berge DA, Powell JJ (2005) Effect of bone turnover and $\mathrm{BMD}$ of low dose oral silicon as an adjunct to calcium/vitamin D3 in a randomized placebo-controlled trial. J Bone Miner Res 20:S172

Van Landeghem GF, De Broe ME, D'Haese PC (1998) Al and Si: their speciation, distribution, and toxicity. Clin Biochem 31(5):385-397

Zioła-Frankowska A, Dąbrowski M, Kubaszewski Ł, Rogala P, Frankowski M (2015) Factors affecting the aluminium content of human femoral head and neck. J Inorg Biochem 152:167-173

Zioła-Frankowska A, Kowalski A, Dąbrowski M, Rogala P, Kubaszewski Ł, Frankowski M (2016) An analysis of factors affecting the mercury content in the human femoral bone. Environ Sci Pollut Res. doi:10.1007/s11356-016-7784-9 